\title{
Transportin HIV-1 by tRNAin and CAr
}

\author{
Lihong Zhou ${ }^{1,2}$, Elena Sokolskaja ${ }^{1,2}$, Clare dolly ${ }^{1,2}$, William James ${ }^{3}$, Sally A Cowley ${ }^{3}$, Ariberto Fassati, ${ }^{1,2^{*}}$ \\ From Frontiers of Retrovirology 2011 \\ Amsterdam, The Netherlands. 3-5 October 2011
}

\section{Background}

To replicate, the human immunodeficiency virus type 1 (HIV-1) must access the nucleus of infected cells and integrate into host chromosomes, however little is known about the events occurring post-nuclear entry but before integration. Transportin 3 (Tnp3) is a karyopherin that is required for HIV-1 infection at a step at or post-nuclear entry therefore understanding how Tnp3 works will inform on such early events in the HIV-1 life cycle.

\section{Materials and methods}

To better understand the function of Tnp3 in the HIV-1 life cycle, we have generated Tnp3 knock down cells, including $\mathrm{CD} 4+\mathrm{T}$ cells and macrophages, and examined the step of the life cycle blocked. We performed pull down assays with viral particles and nuclear export assays using viral and T7 synthesized tRNAs.

\section{Results}

In contrast to current models, we found that Tnp3 promotes HIV-1 integration in different cell types, but has little effect on viral nuclear import. Furthermore Tnp3 bound the viral capsid proteins and tRNAs incorporated into viral particles in pull down assays. The C-terminal region of Tnp3 was required for binding to viral capsid and tRNAs. Interaction between Tnp3, capsid and tRNAs was stronger in the presence of RanGTP, consistent with the possibility thatTnp3 is an export factor for these substrates. In agreement with this interpretation, we found that Tnp3 exports from the nuclei viral tRNAs in a RanGTP-dependent way. Tnp3 also bound and exported from the nuclei some species of tRNAs with a defective 3'CCA end. Depletion of Tnp3 in infected cells resulted in a re-distribution of HIV-1 capsid proteins between nucleus and cytoplasm however HIV-1 bearing the N74D mutation in capsid, which was

${ }^{1}$ Wohl Virion Centre, University College London, London, WC1E 4BT, UK Full list of author information is available at the end of the article insensitive to Tnp3 depletion, did not show such a nucleocytoplasmic redistribution of capsid proteins.

\section{Conclusions}

We propose that HIV-1 retains viral tRNAs and some capsid proteins in order to enter the nucleus of infected cells. However such viral components must be displaced to facilitate integration. Tnp3 promotes HIV-1 integration by displacing any capsid and tRNA that remain bound to the viral complex after nuclear entry. The results provide evidence for an unanticipated step of the HIV-1 life cycle that connects the tRNA nucleocytoplasmic trafficking pathway in human cells and viral infection.

\begin{abstract}
Author details
${ }^{1}$ Wohl Virion Centre, University College London, London, WC1E 4BT, UK. ${ }^{2} \mathrm{MRC}$ Centre for Medical Molecular Virology, Division of Infection \& Immunity, University College London, London, WC1 E4BT, UK. ${ }^{3}$ Sir William Dunn School of Pathology, University of Oxford, South Parks Road, Oxford, OX1 3RE, UK.
\end{abstract}

Published: 3 October 2011

doi:10.1186/1742-4690-8-S2-O3

Cite this article as: Zhou et al:: Transportin HIV-1 by tRNAin and CAr. Retrovirology 2011 8(Suppl 2):03.

Submit your next manuscript to BioMed Central and take full advantage of:

- Convenient online submission

- Thorough peer review

- No space constraints or color figure charges

- Immediate publication on acceptance

- Inclusion in PubMed, CAS, Scopus and Google Scholar

- Research which is freely available for redistribution

Submit your manuscript at www.biomedcentral.com/submit
C Biomed Central

C 2011 Zhou et al; licensee BioMed Central Ltd. This is an open access article distributed under the terms of the Creative Commons Attribution License (http://creativecommons.org/licenses/by/2.0), which permits unrestricted use, distribution, and reproduction in any medium, provided the original work is properly cited. 